\title{
OVERLAPPING BETWEEN PROVINCIAL REGIONAL REGULATIONS WITH REGENCY/MUNICIPAL LOCAL REGULATIONS ON THE REGULATED MATERIAL VIEWED FROM THE LAW NUMBER 12 OF 2011 REGARDING ESTABLISHMENT OF LEGISLATION
}

\author{
By;
}

Iip Septian, Amancik, PE. Suryaningsih

\begin{abstract}
The occurrence of overlapping between provincial regional regulations and regency/municipal regulations on the same material may create legal problems, because if they are not properly regulated, then authority in the implementation and enforcement of overlapping regional regulations becomes biased, this condition resulted in the failure to fulfill the justice and legal certainty aspects, as well as the benefit aspect, because there are dual regulatory arrangements, which are the regency/municipality regulations and the provincial regulations, in which hierarchically the two regional regulatory instruments are unequal, where the provincial regulation has a higher position than regency/municipal regulations. The similarity of content material between provincial and regency/municipal regulations as referred to in the provisions of Article 14 of Law Number 12 Year 2011 concerning the Establishment of Legislation makes it possible to regulate the same material between provincial and regency/municipal regulations. In the context of provincial and regency/municipal regulations governing the same material, then orders, restrictions, permits and licenses must be clear and resolute, where the regency/municipal regulations cannot contain different orders, prohibitions, licenses and permits which has been formulated in the provisions of the provincial regulation, or in other words, the norm formulation in regency/municipal regulations shall not be contradictory to the norms regulated in provincial regulations. Essentially, regency/municipal regulations can only regulate matters that have not been regulated in the above legislation.
\end{abstract}

Keywords: Overlapping of Regional Regulations, Provincial and Regency/Municipal Regulations, Regional Regulation Materials 


\section{A. INTRODUCTION}

\section{Background of the Study}

The Unitary State of the Republic of Indonesia as a state of law (rechtstaat) as stated in Article 1 paragraph (3) of the 1945 Constitution of the State of the Republic of Indonesia implicitly implies that every institutional or state apparatus action, including in the implementation of regional autonomy and duty of assistance must always be guided by the law (legislation). As a concrete step to accommodate the rights and obligations of local governments in the state of law, a juridical instrument is needed in running the government in order to realize the government and development in the region so that it runs in an organized, integrated and planned direction. The form of juridical instruments as mentioned above comes in the form of local legal products either regulating or defining(beschikking).

Regional Regulations or those understood in the scientific world as "local legislation", "local law", "local wet", or local law ${ }^{1}$, are one form of legislative enforcement. Essentially, the authority to regulate comes from the authority determined by the legislator. In certain cases, however, local legislation may also self-regulate matters which, although not explicitly delegated by the law, are deemed necessary to be regulated by the regions to exercise the widest possible regional autonomy as intended by Article 18 paragraph (3) and paragraph (4) of the 1945 Constitution. $^{2}$

Regional regulations have a decisive role in the implementation of regional government, including: ${ }^{3}$

$$
\text { Firstly, "Regional }
$$
regulation determines the direction of development and governance in the regions. As the highest public policy in the regions, the regional regulation should be a reference

\footnotetext{
${ }^{1}$ JimlyAsshiddiqie, PerihalUndangUndang, RajawaliPers, Jakarta, 2011, p.65.

${ }^{2}$ Ibid, p. 190

${ }^{3}$ Dayanto and AsmaKarim, Peraturan

Daerah Reponsif

(PondasiTeoritikdanPedomanPembentukannya ), Deepublish, Yogyakarta, 2015, p.4.
} 
for all public policies that are made, including as a regional reference in preparing regional development programs. A concrete example is the regional regulation on the Long Term Development Plan (RPJP) and Medium Term Development Plan (RPJM) or Regional Strategic Plan (Renstrada)..."

Secondly, regulation regulations as the basis for the formulation of public policy areas. In order for local regulations on the direction of development and implementation of local government can be operationalized, it is needed provisions or regulations on the implementation of local government. Any form of policy required in the context of governance and development should refer to previous regional regulations or higher laws (if regional regulations have not been regulated).

Thirdly, the local regulation as a social contract in the regions. A social contract is a contractual bond between a public official and a community as stakeholders. The existence of such social contracts affects local government officials as follows; (a) For the local government, the legislative function of giving birth to a regional regulation is the legal basis as well as the mandate of the people to organize the government in order to achieve its objectives, namely improving the welfare of the people through enhancing the empowerment and role of the people, improving public services and regional competitiveness; (b) to the Regional House of Representative $(D P R D), \quad$ the legislation function resulting in regional legislation is the basis for implementing the oversight function on regional regulations and governance.

Fourthly, Regional regulation as supporting formation of regional apparatus and the organizational structure of regional apparatus. The size of regional government organizations is determined by the needs and the ability of the region in the framework of public services. In 
order for the funds in the Regional Revenue and Expenditure Budget $(A P B D)$ to be largely used for public purposes, a more streamlined and effective organizational structure is required.

Viewed from the perspective of implications, decentralization has positive and negative implications for the region. One of the positive implications as mentioned, namely the authority possessed by the regional government to regulate and manage their own household (eigenhuishuonding), so that with such authority, the regions have the space to increase/strengthen their economic resources, thus expected to accelerate the realization of welfare of the local community. While one of the negative implications of decentralization is the existence of a legal instrument in the form of overlapping regional regulations, which in this case is between provincial regulation, with regulation of regency/municipality governing the same object, as a result of its possession of the authority of the provincial and regency/municipal governments in the formation of regional regulations as referred to in Article 18 paragraph (6) of the 1945 Constitution of the State of the Republic of Indonesia, which states that: "Local governments have the right to enact local regulations and other regulations to implement autonomy and duty of assistance".

Such overlap may occur in a ruimtegebied ${ }^{4}$ environment indicating the place of enactment of local regulations, as well as the problem power environment (zakengebied) that is, concerning the problems or issues governed. ${ }^{5}$

Soetomo states that "Whenever a tool of government exceeds the limits of its authority concerning the area in which the competentieterritoriaal is established by law then in this case there is incompetentieratione loci

\footnotetext{
${ }^{4}$ AmiroeddinSyarif, Perundangundangam, dasar, jenisdanteknikmembuatnya, BinaAksara, Jakarta, 1987, p.82.

${ }^{5}$ Ibid
} 
(onbevoegdheidratione loci)". ${ }^{6}$

Furthermore, in the case of local regulations containing sanctions, and the formulation of sanctions is different, then which sanctions should be upheld becomes unclear.

The provision of Article 7 Paragraph (2) of Law Number 12 Year 2011 concerning the Establishment of Legislations states that "The legal force of the Law shall be in accordance with the hierarchy as referred to in paragraph (1)", therefore the provincial regulation shall be legislation that has stronger legal power than the regency/municipal regulations. Referring to the principle

lexsuperioriderogatlegiinferiori, there are juridical consequences that arise, namely the regulation of the regency/municipality should not conflict with provincial regulations, but also the provincial regulation is substantially the rule of law that became the reference or the basis of the formation of

\footnotetext{
${ }^{6}$ Soetomo, PengantarHukum Tata
} Pemerintahan, Usaha Nasional, Surabaya, 1981, p.58. regional regulations of regency/municipality.

Based on the brief description above, the author was interested to raise this issue into the writing of the thesis entitled "Overlapping between Provincial Regional Regulations with Regency/Municipal Local Regulations on the Regulated Material Viewed from the Law Number 12 Of 2011 Regarding Establishment of Legislation".

\section{Identification of the Problem}

From the background above, it can be identified that the problem was: How was the arrangement of the same object in provincial regulation and regency/municipal regulation viewed from the Law Number 12 Year 2011 on the Establishment of Legislation?

\section{B. RESEARCH METHOD}

\section{Type of Research}

The conducted study was a normative legal research or literature research, which aims to solve legal issues and provide prescriptions on what should be 
done. ${ }^{7}$ The nature of this study was prescriptive $^{8}$ that is giving guidance or provisions based on legislation.

\section{Research Approach}

The approach used in this study was the statutory approach (statute approach), which was by reviewing legislation relating to legal issues concerning overlapping arrangements between provincial regulation and regency/city regulation on the same object, reviewed from Law Number 12 Year 2011 on the Establishment of Legislations.

\section{Type of Legal Material}

The legal materials used in this research were in the form of primary legal materials, secondary legal materials, and tertiary legal materials, which include:

\section{Legal Material Analysis}

Analysis of legal materials in this study firstly began by selecting the field to be studied. After the field has been

${ }^{7}$ Peter Mahmud Marzuki, PenelitianHukum, Jakarta, KencanaPrenada Media Group, 2009. p.141.

${ }^{8}$ HerawanSauni, MetodePenelitian, bahan Ajar, Bengkulu, 2004, p.2 determined, then it was searched the legislation that regulate all aspects related to the field under study. These aspects constitute a framework, to compile the classification of legislation that have been selected, to be analyzed.

C. RESULTS OS THE STUDY AND DISCUSSION

\section{The Regulation on the Same} Object in Provicial and Regency/Municipal

\section{Regulations}

S.J. Fockema Andreae stated that the term "legislation" (legislation, wetgeving, or gesetzgebung) has two different meanings, namely: ${ }^{9}$

1) the legislation is a process of establishment/process of state regulations of the establishment, either at central level or at the regional level.

2) The legislation is all state regulations, which is the result of the establishment of regulations, both at the

\footnotetext{
${ }^{9}$ Maria Farida Indrati Soeprapto, ibid.
} 
central and at the regional level.

Substantively, it can be seen that the S.J. Fockema Andreae divides the definition of legislation into two, namely;first, the legislation in a formal interpretation, namely the process of establishment, which in the context of the area includes the process of establishing legislation at central and regional level. ${ }^{10}$ Second, is the definition of legislation in materially, ie, as a legal product manifold regulation (Regeling) countries, both the rules at national and regional level, where the rules the central level of the scope of enforceability up in the area, while local regulations apply limited the area where the scope of the regulation made it.

Legislation as a process of formation as proposed by S.J. Fockema Andreae above, in the

\footnotetext{
${ }^{10}$ The author argues that the central and local context in the definition of legislation raised by S.J. Fockema Andreae refers to the legislation in unitary states (eenheidstaat), where there is division./areaconsisting of national and local.
}

context of the Unitary Republic of Indonesia, deductively includes two aspects, namely the stages/mechanisms of the establishment, the right establishing institution/has the authority to form a legislation.

Legally, formal stages of the legislation establishmentare referring to the provisions of Article 1 paragraph 1 of Law Number 12 of 2011 on the Establishment of legislation, which states as follows:

Making Rules is forming Rules of legislation which includes the stages of planning, preparation, discussion, approval or determination, and promulgation.

Based on the formulation of the provisions of Article 1 paragraph 1 of Law Number 12 of 2011, as mentioned above, it is known that the stages of the establishment of legislation that consist of planning, preparation, discussion, approval or determination, and 
promulgation, where the stages are the same applies, both at the central and regional levels, ${ }^{11}$ or in other words, there are no differences in the mechanism of the formation stages of legislation, both at the central and local, even though the object-instrument / type of legislation that can be formed by the centre, and which can be formed by the different regions. $^{12}$

Regarding regulation of the same Material in provincial and regency/city regulations, which may be described as follows:

1) Positive law, the law, which in this case is the provincial regulations and regencies regulations/ applicable and has binding legal force.

2) The law is based on facts, or the established

\footnotetext{
${ }^{11}$ can also be expressed by the uniformity of treatment.

${ }^{12}$ In the context of this research, legislation that may be established in the region referred to the local regulations.
}

law is certain. In the case the law is provincial and local of regency/city regulations that govern the same object, the provisions stipulated in the provincial regulation shall be explicit, clear, non-interpretive, and not overlapping between the provisions stipulated in regulations provinces with the provisions set forth in the regency/city regulations.

3) In fact (the facts) should be formulated clearlyto avoid errors in interpretation in addition to easy to implement, it resembles the previous item, in which case the formulation can be strengthened with the provisions of the explanation is the official interpretation of the maker of the legislation, as a preventive measure 
against erroneous interpretation, so that it can be implemented properly.

4) The positive law should not be easy to change. In the contemporary context, this element cannot be fulfilled again with the state of moving conditions that move dynamically, where changes in legislation can occur quickly, especially on local regulations. Changes or revocation of local regulations can occur quickly in accordance with the emerging legal requirements and political aspects that affect it, and by remembering the hierarchy of local regulations itself as an autonomous legislation that is domiciled under national legislation, changes in legislation that are higher in level than local regulations have a very relevant relationship to changes in local regulations. Changes in laws and regulations that are higher than the local regulations on which the regional regulation is based, will legally result in changes to the regional regulations. This condition also applies in the event of revocation of a statutory regulation. In addition to the effect of changes in legislation and revocation with non-litigation change and revocation mechanisms, there is also a cause for changes in local regulations resulting from litigation actions in legislation.

2. Limitation of Regulation in the Regional Regulation Based on Division of Authority of Government Affairs Between Provincial Region and Regency/City Region.

The materials content that regulated in the provincial and regency/city regulations are same, this causedthere are the similarities of government 
affairs which are the regional authorities, both provincial and regency/city, as referred to in the provisions of Article 11 and Article 12 of the Act Number 23 of 2014 on Regional Government, which states as follows:

Article 11:

(1) (1) Affairs concurrent administration as referred to inArticle 9 paragraph (3) which is composed of theRegional authority of Government Affairs andGovernment

Affairs Mandatory Options.

(2) Mandatory

Government Affairs referred to in paragraph (1) shall consist of Government Affairsrelating to Basic Services and Government

Affairsthat is not related to the Basic Services.

(3) Mandatory

Government Affairs relating tofundamental services referred to in paragraph (2) isthat the majority of Government Affairs Mandatorysubstance is a fundamental service..

Article 12:
(1) Mandatory

Government Affairs relating to BasicServices as referred to in Article 11 paragraph (2)shall include:
a. education;
b. health;
c. public works and
arrangement of space;
d. housing and residential areas;
e. peace, public order, and protection of society; and
f. social.

(2) Mandatory

Government Affairs are not related tothe Basic Services as referred to in Article 11paragraph (2) shall include:
a. workforce;
b. empowerment of women and protection of children;
c. food;
d. land;
e. the environment;
f. population administration and civil registration;
g. community empowerment and village;
h. population control and 


\author{
family \\ planning; \\ i. nexus; \\ j. communication \\ and informatics; \\ k. cooperatives, \\ small \\ businesses, and \\ medium; \\ 1. capital \\ investment; \\ m. youth and sport; \\ n. statistics; \\ o. coding; \\ p. culture; \\ q. library; and \\ r. archival.
}

(3) Government Affairs options referred to in Article11 paragraph (1) shall include:
a. marine and fisheries;
b. tourism;
c. agriculture;
d. forestry;
e. energy and mineral resources;
f. trade;
g. industrial; and
h. transmigration. industry; andtransmigrati on.

There is a division of authority over government affairs as mentioned above, between the provincial government and the local regency/city government, as referred to in the provisions of Article 13 paragraph (1) of Law Number 23 Year 2014 regarding Local Government which states the following:

Article 13:

(1) The division of government affairs concurrent between local and central government and theprovince of districts/cities as referred to in Article 9paragraph (3) is based on the principle ofaccountability,

efficiency, and externalities, as well as the national strategic interests.

Explanation of Article 13 paragraph (1) of Law No. 23 of 2014 states the following:

Article 13

\section{Paragraph (1)}

What is meant by the "principle of accountability" in this provision is responsible for the implementation of a Government Affairs determined based on its proximity to the area, scale, and scope of the impact caused by the implementation of a Government Affairs?

What is meant by the "principle of efficiency" in this provision is the organizer of a Government Affairs determined based on a comparison of the level of the highest efficiency can be obtained. 
The provisions of Article

What is meant by "principle of externalities" in this provision is the organizer of a Government Affairs determined based on broad, scale, and scope of the consequences of the implementation of a Government Affairs?

What is meant by "the principle of national strategic interests" in this provision is the organizer of a Government Affairs is determined based on the consideration in order to maintain the integrity and unity of the nation, safeguard the sovereignty of the State, the implementation of foreign relations, the achievement of strategic programs of national and other considerations set forth in the provisions of the legislation.
13 paragraph (3) and (4) of Law Number 23 Year 2014 on Local Government states the following:

Article 13:

(3) Based on the principles referred to in paragraph(1) criteria Government Affairs under the authority of the provincial Regions are:

a. Government Affairs, which are located across districts/cities;

b. Government Affairs that users cross districts /cities;

c. Government Affairs that the benefits or negativeeffects of the cross of districts/cities; and/or

d. Government Affairs who use its resources moreefficiently when it is done by the Provincial.

(4) Based on the principles referred to in paragraph(1) criteria Government Affairs under the authorityof districts/cities are:

a. Government Affairs, which are located in the District / City;

b. Government Affairs that users in the District /City;

c. Government Affairs that the benefits or negativeimpact only 
in District / City; and/or

d. Government Affairs who use its resources moreefficiently when it is done by District / City.

Referring to the provisions of Article 13 paragraph (3) of Law Number 23 of 2014 as mentioned above, in the aspect of governance arrangements with legal instruments in the form of regional regulations, the provision of Article 13 paragraph (3) of Law Number 23 of 2014 as intended is the provisions that must be obeyed as the content constraints set forth in the provincial, regency and municipal regulations, such as to avoid overlapping arrangements.

3. The Solution Against Same Objects Between Provincial Regulations and Regency/ Municipal Regulations Viewed From Law Number 12 of 2011 on the Establishment of

Legislation.
The similarity of material content between provincial and regency/city regulations as referred to in the provisions of Article 14 of Law Number 12 of 2011 concerning the Establishment of Laws and Regulations makes it possible to regulate the same object between provincial and regency/cityregulations.But keep in mind that there is a principle of the formulation of legislation as referred to in the provisions of Article 5 of Law Number 12 of 2011 concerning the Establishment of Laws and Regulations, and the principle of material content of legislation as referred to in the provisions of Article 6 of Law Number 12 of 2011 concerning the Establishment of Laws and Regulations, as well as the principle of dividing the authority of government affairs between provincial and regency regency/cityregulations in the provisions of Article 13 paragraph (1) of Law Number 23 of 2014 on Regional 
Government, and the sharing of authority limits on the affairs of the governance between provincial and district / city government as referred to in Article 13 paragraph (3) and paragraph (4) of Law Number 23 of 2014 on Regional Government, so that there is no conflict in the aspect of the (ruimtegebied) environment, and the (zakengebied) environment, and the emerging legal needs can be effectively and efficiently implemented in the implementation and enforcement aspects of the future. In addition, in the formal formation mechanism of the legislation, in the planning, arrangement, and discussion phase, it should be carefully reviewed the regulation of legal suitability with the instrument of legislation in the form of regional regulations, namely whether the legal requirement that appears appropriate / must regulate by provincial regulations, or sufficiently with regency / municipal regulations.
A comprehensive academic study is required in the formulation of local regulations because in the Academic Manuscripts it regulates matters concerning theoretical studies and empirical practice, evaluation and analysis of relevant legislation, philosophical, sociological and juridical grounds, range, the direction of arrangement, and the scope of the material content of local regulations. ${ }^{13}$ In addition, it is also necessary to harmonize the design of local regulations that holistically review the draft local regulations that will be applied in the area. In addition, the elements of community participation, and the enhancement of the competence of local regulators into elements that are deemed necessary to be further improved.

\footnotetext{
${ }^{13}$ See Attachment I of Law Number 12 of 2011 on the Establishment of Legislations
} 


\section{CLOSING}

\section{Conclusion}

a. Arrangement of the same object between provincial regulation and regency/municipal regulation is permissible (given space) by Law Number 12 of 2011 concerning the Establishment of Legislation, such matter because of the content material which is regulated in provincial regulation and the content material that is regulated in a Regency/city regulation are in the same content material, as regulated in the provisions of Article 11 and Article 12 of Law Number 23 of 2014 on Regional Government. The arrangement of the same object between provincial and regency/city regulations can be carried out as long as it meets the principles of the formation and principle of content in legislation, as well as the principle of dividing the authority of government affairs between provincial and district / municipal governments.

b. In order to avoid overlapping arrangements in a regulatory material similarity, where in this context the content is regulated by provincial regulations, and regulated by Regency/city

regulations, the fulfillment of the legal certainty aspect becomes so important in order to avoid conflict between regulations regency/city areas with provincial regulations resulting from overlapping arrangements of 
different provisions, or in other words, the legal certainty must be fulfilled in order for the regional regulations to be implemented and enforced (law enforcement ) to its violation. The aspect of legal certainty is an inseparable feature of the law especially for written legal norms, as the sound of the principle "Ubi juice incertum, ibi jus nullum" which means "where there is no legal certainty, there is no law".

\section{(4) Suggestion}

The solution to the arrangement of the same object between the provincial regulation and the Regency/city regulation reviewed from Law Number 12 of 2011 is by the formation of regional regulations that are consistent with the principles, namely the principle of formation, the principle of content material, and the principle of the division of authority of government affairs between the government provincial and regency/local governments, wherein the formation of a comprehensive academic texts on the necessity of arranging an object with local regulations, and also increasing the participation of the community in the formation of regional regulations, and enhancement of the competence of local regulators in the field of legislation.

\section{REFERENCES}

Amiroeddin Syarif, Perundangundangan, dasar, jenis dan teknik membuatnya,

Bina

Akasar,Jakarta, 1987.

Jimly Asshiddiqie, Perihal UndangUndang, Rajawali Pers, Jakarta, 2011.

Peter Mahmud Marzuki, Penelitian Hukum, Jakarta, Kencana Prenada Media Group, 2009.

Soetomo, Pengantar Hukum Tata Pemerintahan", Usaha Nasional, Surabaya, 1981 
Herawan Sauni, Metode Penelitian, Undang-Undang Nomor 23 Tahun Bahan Ajar, Bengkulu, 2004.

Undang-undang Dasar Negara Republik Indonesia Tahun 1945 Peraturan Menteri Dalam Negeri Undang-Undang Nomor 12 Tahun 2011 tentang Pembentukan Peraturan Perundang-Undangan 2014 tentang Pemerintahan Daerah Nomor 80 Tahun 2015 tentang Pembentukan Produk Hukum Daerah 